\title{
The potential contribution of the natural products from Brazilian biodiversity to bioeconomy
}

\author{
MARILIA VALLI, HELENA M. RUSSO and VANDERLAN S. BOLZANI \\ Núcleo de Bioensaios, Biossíntese e Ecofisiologia de Produtos Naturais (NuBBE), Departamento \\ de Química Orgânica, Instituto de Química, Universidade Estadual Paulista 'Júlio de Mesquita \\ Filho’, Av. Prof. Francisco Degni, 55, 14801-970 Araraquara, SP, Brazil
}

Manuscript received on August 22, 2017; accepted for publication on September 20, 2017

\begin{abstract}
The development of our society has been based on the use of biodiversity, especially for medicines and nutrition. Brazil is the nation with the largest biodiversity in the world accounting for more than $15 \%$ of all living species. The devastation of biodiversity in Brazil is critical and may not only cause the loss of species and genes that encode enzymes involved in the complex metabolism of organisms, but also the loss of a rich chemical diversity, which is a potential source for bioeconomy based on natural products and new synthetic derivatives. Bioeconomy focus on the use of bio-based products, instead of fossil-based ones and could address some of the important challenges faced by society. Considering the chemical and biological diversity of Brazil, this review highlights the Brazilian natural products that were successfully used to develop new products and the value of secondary metabolites from Brazilian biodiversity with potential application for new products and technologies. Additionally, we would like to address the importance of new technologies and scientific programs to support preservation policies, bioeconomy and strategies for the sustainable use of biodiversity.
\end{abstract}

Key words: Brazilian biodiversity, natural products, medicinal chemistry, database.

\section{INTRODUCTION}

The development and growth of our society has been based on the use of biodiversity. Plant species, particularly those identified as having nutrition and medicinal uses, were essential for human survival. Ancient populations around the planet established a set of useful plant species by a long experienced selection. According to the

Correspondence to: Vanderlan da Silva Bolzani

E-mail: bolzaniv@iq.unesp.br

* Contribution to the centenary of the Brazilian Academy of Sciences.
World Health Organization, the use of traditional medicine is growing in developed countries as a complimentary use and reaches $80 \%$ in Africa, that depends essentially on plants for primary health care (WHO 2017a). Pharmaceutical companies are interested in investigating plants as source for new lead structures and also for the development of standardized herbal agents with proved efficacy, safety and quality (Calixto 2000). The medicinal properties of plants have been the focus of scientific researches in the field of natural products, and great advances were achieved in the last century (Valli 
et al. 2012). Given the number of plant species on Earth and the several biosynthetic pathways capable of producing extraordinary chemical diversity, biodiversity in tropical and equatorial environments offers a particularly rich potential in biologically active compounds that can be used as models for medicinal chemistry and drug discovery (Bolzani et al. 2012).

The term biodiversity can be defined as the variety and complexity among living organisms, encompassing species, DNA, genes, proteome, metabolome and their interaction with their ecological systems (Wilson 1999, Noss 1990). Associated with biodiversity, there is a rich diversity of natural compounds with peculiar structures that are still one of the most sophisticated sources of new molecular models for medicinal chemistry, development of new drugs, agrochemicals, fragrances, cosmetics, and food supplements. Among the 1211 new low molecular weight prototypes (known as New Chemical Entities - NCE) introduced on the world market as pharmaceuticals during the period 1981-2014, 60\% are derived from natural products, mimetics or designed from natural product structures (Newman and Cragg 2016).

Brazil is the country with the largest biodiversity in the world and has been taking actions to preserve it, being the first nation to sign the Convention on Biological Diversity in 1992. It stands out for having a mega biodiversity, accounting for more than $15 \%$ of all living species in the planet (MMA 2017). Brazil has an area of $8,511,996 \mathrm{~km}^{2}$ in which six terrestrial biomes are distributed (the Amazon rainforest, the Caatinga, the savana-like Cerrado, the Atlantic Forest, the swamp known as the Pantanal and the Pampas) and a sea coast of 7,491 km hosting three marine ecosystems and twelve major hydrographic regions (MMA 2017). Two of these ecosystems, the Atlantic Forest and the Cerrado, are considered hotspots of biodiversity due to the accelerated loss of biological diversity caused by urbanization, agriculture and livestock. These areas contain several species that can be threatened with extinction in the near future, and the biological knowledge would also be lost since they contain only $0.5 \%$ of the approximately 300,000 species of plants cataloged and known in the world as endemic to these environments (MMA 2017, Myers et al. 2000).

The rate of Brazilian natural resources devastation is alarming and many species are at risk of extinction. Furthermore, considering the loss of knowledge of traditional population on the uses of these species, countless natural products of distinct classes and completely unknown structural types can be lost, many of them of inestimable scientific and technological value. To reverse this situation, it is important to create interdisciplinary research programs involving biologists, chemists, botanists and pharmacologists dedicated to the rational use and conservation of the remaining forest areas.

The devastation of biodiversity in Brazil may not only cause the loss of rich chemical diversity, essential for prospecting hits and leads of effective drugs, but also the loss of genes that encode enzymes involved in the complex metabolism of plants (Silva et al. 2010).

The economical interest in the natural resources of "Terra Brasilis" dates from the colonization period. The first Brazilian exploration based on extractive of the country was the exploration of Caesalpinia echinata (Fabaceae), known as paubrasilia, used in Europe as source of natural dye (Silva et al. 2010). As a result, the occupation of the coastal area of Brazil began in this period and currently about $60 \%$ of the Brazilian population lives in this region (SOS Mata Atlântica 2017). This predatory occupation almost caused the extinction of a whole Brazilian biome, the Atlantic forest, of which only about $7 \%$ remains. Therefore, the combination of social, political and economic welfare with the rational use of natural resources is of extreme importance. Despite the devastation 
process of some biomes, Brazil has shown commitment in the conservation and sustainable use of biodiversity, being the key negotiator of the Nagoya protocol (Pavarini et al. 2012).

Apart from the indiscriminate predation of biodiversity, the world population is facing serious problems such as maintaining quality of life, improving quality in sub-developed countries and making a sustainable use of Earth resources (Brugge et al. 2016). Population random growth is the main cause of these problems. Statistics indicate that there will be more than nine billion people in the world by 2050, and with a higher proportion increasing their quality of life (which could be excellent), it can become unsustainable since resources are finite. The current economic model can no longer be sustained by the world, and an economy based in bio-products is not only attractive as a gain in quality of life, but also a mandatory commitment to the Earth (Philp 2015). There are two aspects that could work together to achieve this important task: public policies and implement of new technologies. New technologies bring "greener", safer, renewable, waste-free methods to replace old processes and public policies are essential to apply them in an organized and evenly manner. These two aspects are the core of the new world sustainability strategy called bioeconomy (El Chichakli et al. 2016).

\section{BIOECONOMY}

Bioeconomy is not a business segment or a specific scientific innovation, but includes "all economic activity derived from bio-based products and processes which contribute to sustainable and resource-efficient solutions to the challenges we face regarding food, chemicals, materials, energy production, health and environmental protection" (RSB 2017). Bioeconomy is now part of the strategic actions of more than 40 countries (E1 Chichakli et al. 2016). It uses bio-based products, commodities and electricity, instead of fossil-based ones. Bioeconomy is the key element that could address some of the important challenges faced by society, especially regarding energy generation by replacing non-green fossil fuels with cleaner alternatives (Philp 2015). It comes to assist the replacing and changing the world's economical systematic in order to prevent collapse. We could take metabolic engineering as an example of new technologies that had considerably broadened the variety and amount of compounds now accessible that were once restricted to naturally occurring metabolites (Murphy 2011).

Brazil could be a leader in this economic transition since it is granted with all the conditions to be a sustainable model. It has the largest biodiversity of the globe, suitable climate condition, abundant land, relative small population and plenty of natural resources. Infrastructure has to be improved and greener technologies must be incorporated to industry and agriculture. Brazilian economic success heavily relied on commodity exports. This commodity success deviated attention from important actions that should have been done in structural (infrastructure, political reforms) and institutional (education, research, institutes) investments. Brazil failed in converting its economic boom into knowledge, as can be seen by the global share of high added value export that scarcely changed in the last 20 years (Gallagher and Porzecanski 2010). Brazil should now "run after the lost time" and heavily invest in turning commodities to high added value products. That means investing evenly in education, science and innovative industry. Maybe more important than investment, Brazil should focus on improving public management and supporting innovation by reducing bureaucracy. As an example, patent application in Brazil expects to wait 11 years to be approved, but this has started to be addressed (INPI 2017). 
Considering the chemical and biological diversity present in Brazil, there is a universe of opportunities for bio-based innovation. In the next section we would like to point a few examples of Brazilian natural products that were successfully used (some by foreign countries) to develop new products and give evidence of the country biodiversity potential.

\section{THE POTENTIAL OF BRAZILIAN NATURAL PRODUCTS}

Secondary metabolites play a key role in plants by regulating, balancing, adapting to habitats, physical and climatic factors and protecting against pathogens and predators. In view of the large territorial extension of Brazil and the different habitats in which the plants had to adapt during their evolution, it is well known that the Brazilian flora has an extraordinary, but underexplored chemical diversity that could be used for the development of bio-based products, including pharmaceuticals, cosmetics, food supplements and agricultural pesticides.

The flora and fauna of the Brazilian Biomes reveal a diversity of compound classes and structural types of secondary metabolites. Plants, fungi, insects, marine organisms and bacteria are sources of biologically active substances, being a rich natural library of hits and drug leads (Barreiro and Bolzani 2009). Natural product chemistry is a traditional research field in Brazil, and until recently, most of the studies have been focused on the fractionation, isolation and structural elucidation of secondary plant metabolites. The study of microorganisms and marine organisms is becoming more common in the national scientific projects, adding a new feature to the chemistry of natural products in Brazil.

The modern phytochemistry in Brazil was introduced by the researchers Dr. Walter B. Mors, Dr. Otto R. Gottlieb and Benjamin Gilbert from the 1950 s to the 1970 s, who contributed greatly to the formation of a new generation of researchers in Brazil. Otto R. Gottlieb was initially interested in the immense biological diversity of the Amazon biome by studying arylpyrones, chromenes and benzophenones in species of the Myristicaceae and Lauraceae families (Silva et al. 2010, Gottlieb and Mors 1980). These natural products are known due to their effects on the central nervous system, and therefore are important for the sedative pharmacological effect (Gottlieb and Mors 1980).

Neolignans are also well studied natural products from Amazonian plants, mainly isolated from Aniba spp. Gottlieb, Yoshida research groups and also several Brazilian researchers published a series of works on phytochemistry, chemosystematic and biological activities of this class of C6-C3 dimers, which classification was designated by Gottlieb himself. Neolignans, as well as lignans, are well known due to the many pharmacological properties, especially antitumor, anti-inflammatory, antileishmanial, and antichagasic (Gottlieb and Mors 1980). Lignans and neolignans of Brazilian species are chemically and biologically well studied, particularly those isolated from Myristicaceae and Lauraceae families. Approximately 350 neolignans and 270 lignans have been described in the literature from plant species of the Brazilian flora (Silva et al. 2010) and about $75 \%$ of these were described by Gottlieb, collaborators and other Brazilian researchers, which main focus were phenolic derivatives.

Natural products from plants of the Brazilian biodiversity are comprehensively reviewed from the pharmaceutical, cosmetic and nutraceutical point of view. Despite the immense chemical and biological resources, few examples of natural products from the Brazilian biodiversity have reached the world market of drugs, and were developed outside of Brazil. The discovery of bradykinin (1) (Figure 1), isolated from the venom of Bothrops jararaca, is one of these examples 


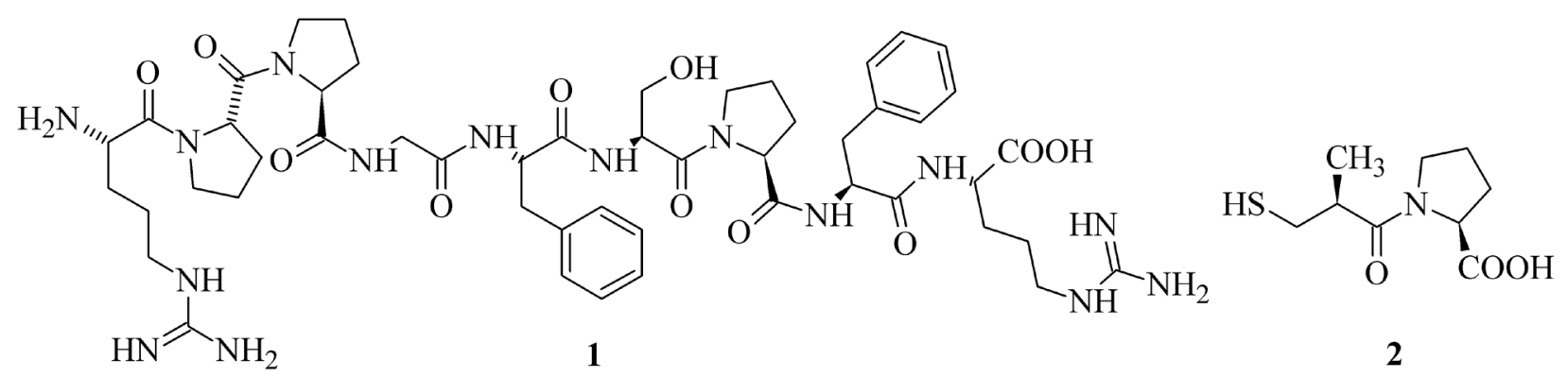

Figure 1 - Structure of bradykinin (1), a peptide extracted from Bothrops jararaca and the drug captopril (2, Captoten $\left.{ }^{\circledR}\right)$ an ACE inhibitor used for the treatment of hypertension designed from molecular simplification of $\mathbf{1}$.

(Ferreira et al. 1970). This peptide is an inhibitor of the angiotensin-converting enzyme (ACE), which is responsible for the conversion of angiotensin I to angiotensin II during the passage through the pulmonary circulation, and an important target for hypertension treatment. Further investigations and structural simplification led to the development of a new class of peptidomimetics, the ACE inhibitors, classically represented by captopril (2), $\left(\right.$ Captoten $\left.^{\mathbb{B}}\right)$ (Figure 1; Buss and Waigh 1995).

The alkaloid pilocarpine (3) (Figure 2) isolated from Pilocarpus sp (Rutaceae) is another successful example of drug development from a natural product isolated from a Brazilian biodiversity plant species. Pharmacological studies have shown that pilocarpine is a muscarinic-type cholinergic agonist. Salagen ${ }^{\circledR}$ (Novartis) was launched as a medicine to alleviate xerostomia due to the abnormality of the salivary glands that are affected by radiation in patients with head and neck cancer in the course of radiotherapy treatment (Horiot et al. 2000).

Concerning drug development, there are no examples of pure drug compounds developed as drugs in Brazil, however, there are some herbal medicines developed completely in Brazil. Natural products from the Brazilian biodiversity have been extensively studied in research groups in Brazil, but the great number of isolated compounds is not consistent with the very few examples of drugs developed. The first drug based on a chemically standardized extract of Cordia verbenaceae

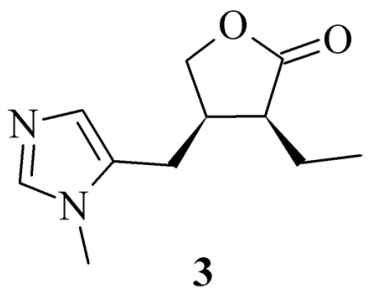

Figure 2 - Pilocarpine (3), imidazole alkaloid active ingredient of Salagen ${ }^{\circledR}$ (Novartis).

(Borraginaceae) was launched a few years ago on the pharmaceutical market as $\operatorname{Acheflan}^{\circledR}$ (Achē). This topical anti-inflammatory drug was completely developed in Brazil, and consists of a mixture of sesquiterpenes of the essential oil of $C$. verbenaceae (Passos et al. 2007, Fernandes et al. 2007). The pharmaceutical industry Achē also launched the anxiolytic standardized herbal medicine Sintocalmy ${ }^{\circledR}$ prepared with the extract of Passiflora incarnata (Passifloraceae) containing the flavonoid vitexin (apigenin-8-C-glucoside) (4) (Figure 3) as one of the active compounds. Besides that, Stryphnodendron adstringens (Mart.) is traditionally used in wound healing, and the pharmaceutical company Apsen Farmacêutica have developed Fitoscar ${ }^{\circledR}$, an ointment based on this species that contain a mixture of phenolic derivatives, mainly condensed tannins (Souza et al. 2007, Minatel et al. 2010). 
<smiles>O=c1cc(-c2ccc(O)cc2)oc2c(C3O[C@H](CO)[C@@H](O)[C@H](O)[C@H]3O)c(O)cc(O)c12</smiles>

4

Figure 3 -The flavonoid vitexin (4), from the Passiflora incarnata extract, and one of the compounds present in the herbal medicine Sintocalmy ${ }^{\circledR}$.<smiles>C=C(C)C1CC=C(C)CC1</smiles>

5

Figure 4 - Limonene (5), a natural product from citrus species.

The few examples of medicines or herbal medicines from species or chemicals from Brazilian biodiversity makes evident that many plant species has no refined study to validate medicinal plants, representing a huge economic potential to be explored.

Biodiversity provides extravagant molecular structures, but not only complex structures are medicinally or economically useful. In fact, simplicity is usually much more useful, and we can get to the concept that less is more. A simple example of a versatile bioeconomy chemical is limonene (5, Figure 4). This natural product abundantly found in citrus fruits (it is a by-product of the citrus industry), is a renewable chemical in several applications such as perfume, flavoring and, more recently, as a green solvent. Brazil is granted with good conditions for citrus growth and is the largest producer of orange in the world, accounting for approximately $40 \%$ of the world production. Limonene is an innovative green chemical and is being applied for a wide variety of environmentally friendly uses such as a bio-based solvent (replacing petroleumbased ones), cleaning agent (conveniently in a formulation with other surfactants) and pesticide ingredient. Limonene has several more properties as anticancer, chemopreventive, detoxifier and anti-asthmatic. It can also be used as a chemical platform to produce higher added valued products. Nevertheless, much of the limonene comprised in the citrus peels are not extracted as a by-product, but are simply wasted (Ciriminna et al. 2014).

\section{SCIENTIFIC PROGRAMS AND PUBLIC POLICIES}

Within the scenario of need for economical changes turning to a more sustainable world, preservation research programs and public policies are of extreme importance. In the research area, in 1999 the 'Fundação de Amparo à pesquisa do Estado de São Paulo'/FAPESP approved the BIOTA/FAPESP Program and one of its objectives is the search for bioactive compounds from São Paulo State biodiversity, aiming at to find new lead molecules from the main biomes Cerrado and Atlantic Forest. This program is a successful example that organized information about Brazilian biodiversity can assist the sustainable use of natural resources, launch of environmental laws and social and economic development (Joly et al. 2010). Some examples of the advances and important information obtained from Brazilian biodiversity in this collaborative program will be presented to highlight its importance.

The Amazonian forest region is a very rich Brazilian biome, and among all the variety of plants it encompasses, several hallucinogen and toxic species can be found. Since pre-Colombian times, the tea obtained from the decoction of these 
plants, including species from Banisteriopsis and Psychotria genera (McKenna et al. 1998), have been used in indigenous rituals, even so nowadays it can also be consumed in rituals of syncretic religions in Brazil, such as "Santo Daime" and "União do Vegetal" (Labate and Feeney 2012). The Ayahuasca is a tea obtained from B. caapi (Malpighiaceae) and is consumed by these religions. However, Tetrapterys mucronata (Malpighiaceae) can occasionally be used in this preparation due to the morphological similarity of these two species. It is known that Banisteriopsis caapi has alkaloids in its chemical composition (Samoylenko et al. 2010), however, there were no studies in T. mucronata genus until recently.

A phytochemical study performed by Queiroz et al. (2014) resulted in the isolation of 22 compounds from the ethanol extract of $T$. mucronata, of which six are new natural products, including two dimeric indole alkaloids (6 and 7 ), one glycosylated lignin (8) and three new phenanthrene derivatives $(\mathbf{9}, \mathbf{1 0}$ and $\mathbf{1 1})$. Since this plant is known for acting in the central nervous system, all compounds isolated were evaluated for the inhibition of acetylcholinesterase activity, and compounds 9 and 10, bufotenine (12), 5-methoxy$\mathrm{N}$-methyltryptamine (13) and 5-methoxybufotenine (14) were active in concentrations below $15 \mu \mathrm{M}$ (Figure 5, Queiroz et al. 2014).

In addition, compounds 12, 13, 14 and 15 (2-methyl-6- methoxy-1,2,3,4-tetrahydro$\beta$-carboline) had not been reported yet as possible constituents of Ayahuasca, therefore, a quantification of these substances by LC-ESI/MS/ MS was performed. It was determined that in the water decoction of T. mucronata, compounds $\mathbf{1 2}$, 13, 14 and 15 were present in concentrations of $2.32 \pm 0.14,0.50 \pm 0.04,1.53 \pm 0.09$ and $0.10 \pm$ $0.01 \mathrm{mg} \cdot \mathrm{g}^{-1}$, respectively. These amounts can increase with an optimum extraction method, which can be achieved by the longer decoction time required to Ayahuasca tea preparation. Compounds
12 and 14 can also be found in toads from the Bufo genus, and these compounds are considered as prohibited drugs in United States, Australia and United Kingdom (Queiroz et al. 2015). These results contributed to a better understanding of the Ayahuasca, which consumption in Brazil is legal, and to emphasize the need of a stricter control in the identification of these species in order to avoid the risk of intoxication.

In the Brazilian territory, there are many tropical fruits that are important for the discovery of bioactive compounds, and its consumption is increasing due to the recognition of their nutritional and therapeutic effects (Zeraik et al. 2011). In the Northeast region, there are several species adapted to the extremophile biome Caatinga. Many fruits from these species play an important role in this region's economy, especially Spondias tuberosa (Anacardiaceae), since it blooms and bear fruits over the dry season. Phytochemical investigations on $S$. tuberosa fruit pulp methanolic extract led to the identification of eight compounds, in which one is a new phenylethanol derivative, 16, and another one is a new benzoic acid derivative, 17, (Figure 6). Compounds 18 and 19 (Figure 6) presented high antioxidant activity by DPPH (2,2-diphenyl1-picrylhydrazyl), ABTS (2,2'-azino-bis(3ethylbenzothiazoline-6-sulphonic acid)) and ORAC (Oxygen Radical Absorbance Capacity) $\left(\mathrm{EC}_{50} 3.51 \pm 0.33 \mu \mathrm{M}, 1.13 \pm 0.80 \mu \mathrm{M}\right.$ and $2.9 \pm$ $0.2 \mu \mathrm{M}$ for 18 and $\mathrm{EC}_{50} 9.65 \pm 0.21 \mu \mathrm{M}, 7.55 \pm$ $0.40 \mu \mathrm{M}$ and $3.4 \pm 0.2 \mu \mathrm{M}$ for 19 respectively), very similar values to the positive control quercetin $\left(\mathrm{EC}_{50} 3.49 \pm 0.23 \mu \mathrm{M}, 2.97 \pm 0.40 \mu \mathrm{M}\right.$ and 4.1 $\pm 0.1 \mu \mathrm{M})$, and an acetylcholinesterase activity inhibition of $\mathrm{IC}_{50} 11.53 \pm 0.59 \mu \mathrm{M}$ and $12.65 \pm$ $0.65 \mu \mathrm{M}$, respectively, comparable to the positive control galantamine $\left(\mathrm{IC}_{50} 2.40 \pm 0.25 \mu \mathrm{M}\right)$ (Zeraik et al. 2016).

Besides that, the dichloromethane extract obtained from $S$. tuberosa pulp was evaluated for induction of quinone reductase activity, a cancer 


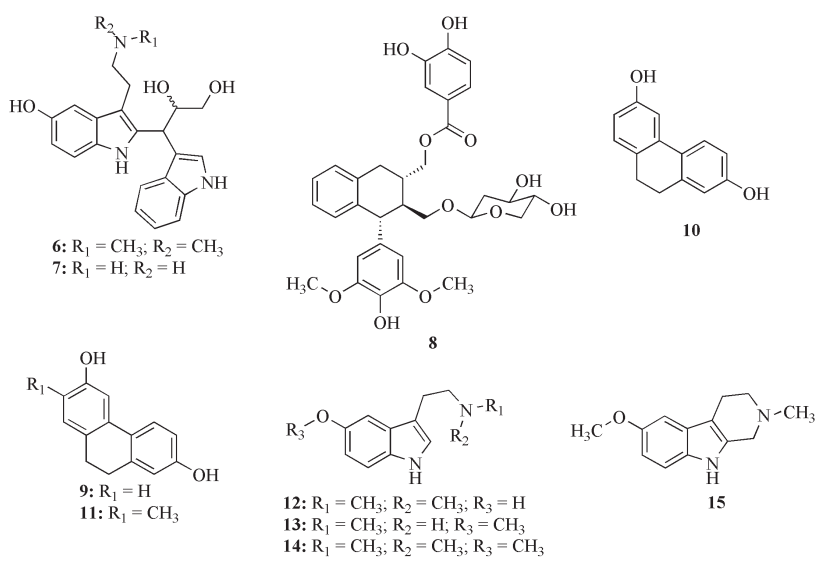

Figure 5 - Compounds isolated from T. mucronata (6-15).

chemopreventive activity assay (Cuendet et al. 2006). This extract presented an induction ratio of 2.8 at $20 \mu \mathrm{g} \mathrm{mL}^{-1}$ in Hepa1c1c7 cells, and the cell viability was $78.6 \%$, indicating a low toxicity of this extract at this determined concentration (Zeraik et al. 2016). Therefore, according to these results, it was possible to identify and to highlight the biological potential in antioxidant and chemopreventive assays of this important functional fruit present in Brazilian Caatinga.

A relatively new research field in our research group is the study of species containing peptides in its chemical composition, especially orbitides, which are peptides cyclized by N-to-C and do not present disulfides linkages. There are several species from Jatropha genus that present this class of compounds and they are known to exhibit a great variety of biological activities (Sabandar et al. 2013) (possibly due to its specificity, metabolic stability and similarity to protein structural patterns), including activity against Plasmodium falciparum, a protozoan responsible for the most severe form of malaria, a neglected disease that affect more than 200,000,000 people each year (WHO 2017b). There are few available drugs for malaria disease treatment, however, the parasites have been gaining resistance and the search for new drugs to fight malaria has increased.
Considering that Jatropha genus is a rich source of bioactive compounds, Pinto et al. (2015) selected aerial parts of Jatropha ribifolia (Euphorbiaceae) for a study. A new orbitide, ribifolin (20, Figure 7), was obtained from the ethyl acetate fraction of the hydro alcoholic extract and, in order to characterize its structure, HRESIMS analysis was initially employed. Knowing the exact mass, a MS/MS analysis was performed, in which a loss of water could be observed initially (due to the ring opening), followed by the losses of amino acid residues. Detailed information of $1 \mathrm{D}$ and 2D NMR spectroscopy were necessary to determine its stereochemistry, such as quantitative amino acid analysis, molecular dynamics/simulated annealing and Raman optical activity calculations and measurements (Pinto et al. 2015).

After isolation and elucidation of compound 20, this peptide was synthesized using the solidphase technique (SPPS) in order to confirm the proposed sequence and to obtain the amounts needed to perform bioassays. In this process, a linear sequence of ribifolin (21) was obtained in addition to the cyclic one. These two substances were evaluated for antiplasmodial activity, being chloroquine the positive control $\left(\mathrm{IC}_{50}=0.3 \mu \mathrm{M}\right)$. The cyclic ribifolin presented a moderate activity of $\mathrm{IC}_{50}=42 \mu \mathrm{M}$ against $P$. falciparum 3D7 strain, while the linear derivative presented a much weaker effect on inhibiting the survival of the parasites $\left(\mathrm{IC}_{50}=519 \mu \mathrm{M}\right)$. This was a very interesting result since it provided evidence that the cyclization step is important to improve the biological activity, mainly due to the minimization of conformational freedom of the molecule, making it more specific. Besides that, a cytotoxicity evaluation was performed, and it was observed that none of the compounds were toxic to kidney cells (HEK293T) at the concentration range tested (0.001-100 $\mu \mathrm{M})$ (Pinto et al. 2015). These results are very stimulating for further orbitides research from species of Euphorbiaceae family. 


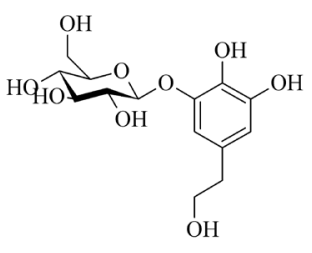

16

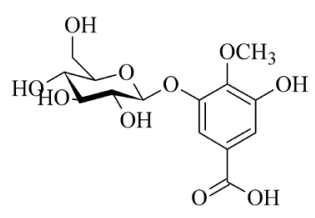

17

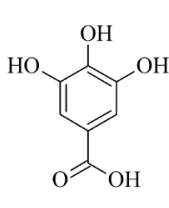

18

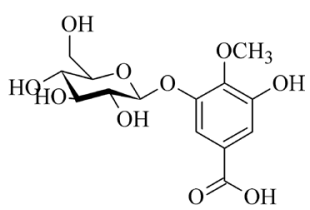

19

Figure 6 - New compounds (16 and 17) and bioactive compounds (18 and 19) isolated from $S$. tuberosa.
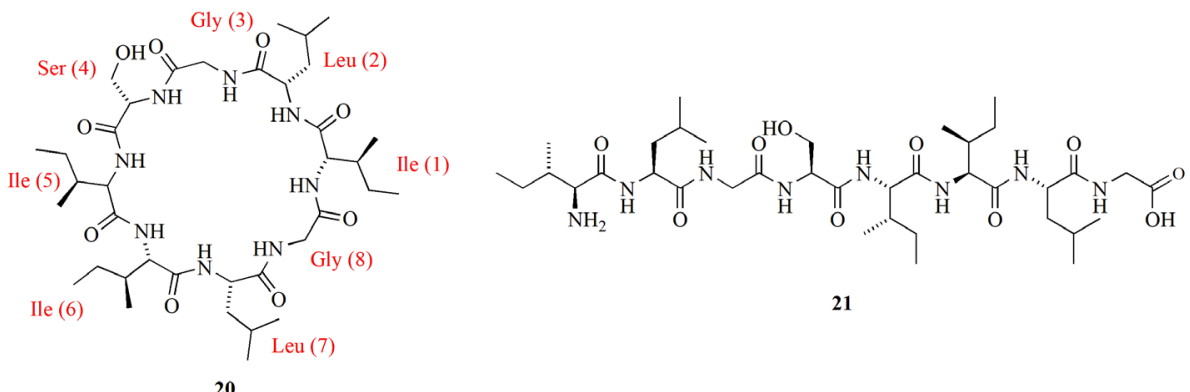

21

Figure 7 - Ribifolin (20), orbitide isolated from Jatropha ribifolia, and its linear derivative (21).<smiles>CC(=O)CCCC[C@@H]1CC[C@@H](OC(C)=O)[C@H](C)N1</smiles>

(-)-3-O-acetyl-spectaline (22)<smiles>CCOC(=O)CSc1ncccc1[N+](=O)[O-]</smiles>

23

Figure 8 - the natural alkaloid (-)-3-O-acetylspectaline (22) isolated from $S$. spectabilis and its derivative (23).

The ornamental species of Senna (Leguminoseae) are known for several applications, and our group has studied Senna spectabilis due to the piperidine alkaloids it produces (Bolzani et al. 1995, Viegas et al. 2004, 2005, Pivatto et al. 2005). A series of pyridine anticholinesterasic compounds were designed using molecular hybridization technique between tacrine and the natural alkaloid (-)-3-O-acetylspectaline (22) isolated from S. spectabilis (Valli et al. 2011). The cholinergic system plays an important role in the treatment of schizophrenia and depression, thus the pharmacological profile of three pyridine compounds was evaluated aiming at potential adjuvants for the treatment of CNS disorders. The results obtained on pyridine compound (23, Figure 8) suggested an efficacy for treating schizophrenia positive symptoms and an antidepressant-like effect (Valli et al. 2015). This compound can be synthesized with good yielding (96\%) and its chemical structure could be further investigated to design new lead compounds. These results reinforce the use of rational approaches for increasing natural products biological activity and prospecting new activities for known compounds.

An interesting study, also focused on $S$. spectablis species, wasperformed withanendophytic fungus that can be found on its leaves, named Phaeoacremonium sp. Three new isoaigialones (A, B and C) and aigialone (compounds 24, 25, 
26 and 27, respectively, Figure 9), were isolated from the ethyl acetate extract of this fungus. These compounds were evaluated against Cladosporium cladosporioides and C. sphaerospermum using bioautography and compounds $\mathbf{2 5}$ and $\mathbf{2 7}$ presented antifungal activity with a detection limit of $5 \mu \mathrm{g}$ (using Nystatin as a positive control at a detection limit of $1 \mu \mathrm{g}$ ), that could be related to a defensive role of these compounds in $S$. spectablis leaves against microbial pathogens. Compounds 24-27 were also evaluated for cytotoxicity performed by MTT assay against HeLa (human cervical tumor cell line) using camptothecin as a positive control $\left(\mathrm{IC}_{50}=0.12 \mu \mathrm{M}\right)$. Compound 27 resulted in an $\mathrm{IC}_{50}$ of $50 \mu \mathrm{M}$ while 25 presented an $\mathrm{IC}_{50}$ value of 100 $\mu \mathrm{M}$, and compounds $\mathbf{2 4}$ and $\mathbf{2 6}$ were inactive (Silva et al. 2017).

One of the most important discoveries of human kind was the penicillin, the first antibiotic described in history. It is produced by the Penicillium chrysogenum fungus and this substance made a remarkable improvement in human life expectancy after its discovery due to the possibility to treat several bacterial infections that used lead to death. Several other antibiotics were developed after penicillin, however, it was observed that bacteria can became resistant to these substances and researches aiming new compounds with similar activity are being developed around the world.

Kielmeyera variabilis (Clusiaceae) is used in Brazilian folk medicine to treat several tropical diseases and bacterial infections. A bioactivityguided fractionation of the ethanolic extract of $K$. variabilis branches was performed in our research group and led to the isolation of a new acylphoroglucinol (28, Figure 10), which the complex structure was elucidated by $1 \mathrm{D}$ and 2D NMR spectroscopic analysis, mass spectrometry and its absolute configuration was determined by electronic circular dichroism. This compound activity was evaluated against several Staphylococcus aureus (MRSA) strains and the in vitro antibacterial activity (MIC) observed for EMRSA-16 was $0.5 \mathrm{mg} \mathrm{L}^{-1}$, a higher activity when compared to the control antibiotic (norfloxacin, MIC $\left.=128 \mathrm{mg} \mathrm{L}^{-1}\right)$ (Coqueiro et al. 2016). This activity corroborated to the uses of this species in folk medicine in Brazil and has opened a possibility for further evaluation of the anti-MRSA mechanism of action.

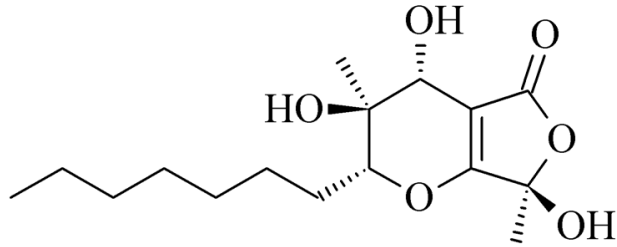

24

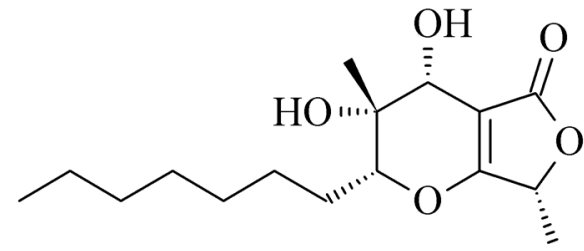

26

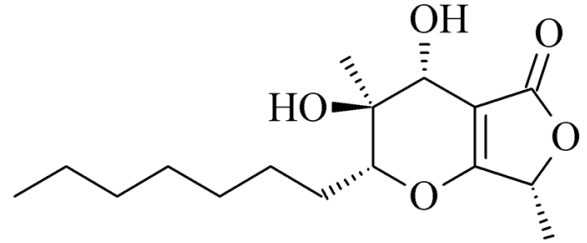

25

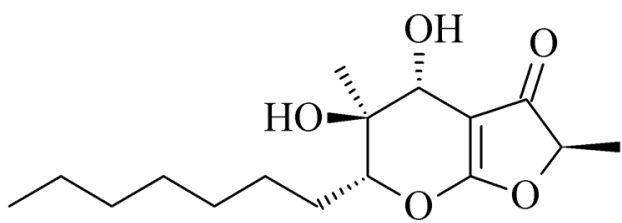

27

Figure 9 - New isoaigialones (24, 25 and 26) and aigialone (27) isolated from Phaeoacremonium sp. 


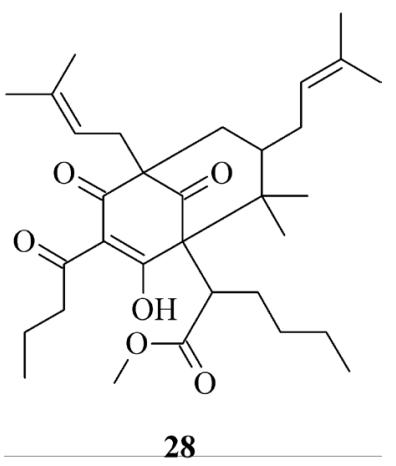

Figure 10 - New acylphoroglucinol (28) isolated from Kielmeyera variabilis.

Another recent program for biodiversity is the NuBBE database: the database of natural products from Brazilian biodiversity. The chemical diversity of the Brazilian species is being catalogued by this project created in 2013, initially with 640 compounds isolated and identified by the Research Group Nucleus of Bioassay, Biosynthesis and Ecophysiology of Natural Products (Valli et al. 2013). $\mathrm{NuBBE}_{\mathrm{DB}}$ currently provides data of more than 2000 compounds of plants, marine organisms, fungi, etc, and contains chemical (metabolic class, chemical structure, physicochemical properties, common and IUPAC name and molecular mass), biological (occurrence, habitat, biological activities), pharmacological and spectroscopic data (Pilon et al. 2017). This database is freely accessible online, where it is possible to search for properties, chemical structure, class of natural products or a combination of molecular or biological criteria (Figure 11, NUBBEDB 2017).

The scientific information published in more than 50 years of studies on Brazilian biodiversity becomes easier to access when standardized, certified and organized in a database. The access and mapping of the molecular heritage of Brazilian biodiversity significantly reduces the time spent in understanding and increases feasibility of applying processes that involve technological research. This information center is freely available online in order to bring benefits both to science and to strengthen the national bioeconomy. Countries like Germany and England have a robust bioeconomy although they do not have a great biodiversity in their territories. In this sense, the objective of $\mathrm{NuBBE}_{\mathrm{DB}}$ is to assist in the development of different fields of Brazilian science, technological development of biodiversity products with high added value and public policies.

The $\mathrm{NuBBE}_{\mathrm{DB}}$ is being used by the scientific community (Villoutreix et al. 2013, Harvey et al. 2015, Kuenemann et al. 2016, Neves et al. 2015, Mohamed et al. 2016), and a work recently completed by our group described a synthetic analogue of the natural product piperlongumine as an inhibitor of breast cancer cell line migration. Piperlongumine (29, Figure 12) is an amide alkaloid isolated from species of Piper having a selective cytotoxic activity for some cancer cell lines (Raj et al. 2011). Piperlongumine was selected for studies from NuBBE Database in a cell migration-based screening with MDA-MB-231 breast cancer cells $\left(\mathrm{EC}_{50}\right.$ of $\left.3.0 \pm 1.0 \boldsymbol{\mu} \mathbf{M}\right)$. A series of analogues of piperlongumine were designed, and the molecular simplified analogue (30, Figure 12) was the most active of the series, surpassing the activity of piperlongumine $\left(\mathrm{EC}_{50}\right.$ of $\left.1.5 \pm 1 \boldsymbol{\mu M}\right)$ and remaining selective with a selectivity index of 4.4 (Valli et al. 2017).

\section{NEW TECHNOLOGIES}

The development of new technologies together with preservation policies is a key strategy for the sustainable use of biodiversity. New analytical approaches have been widely used for understanding the chemical metabolism of biodiversity. The focus has been to understand in a holistic way the relationships and interactions of a living system and its environment, to detect the role of the natural products in these interactions and to identify all molecular components in a 


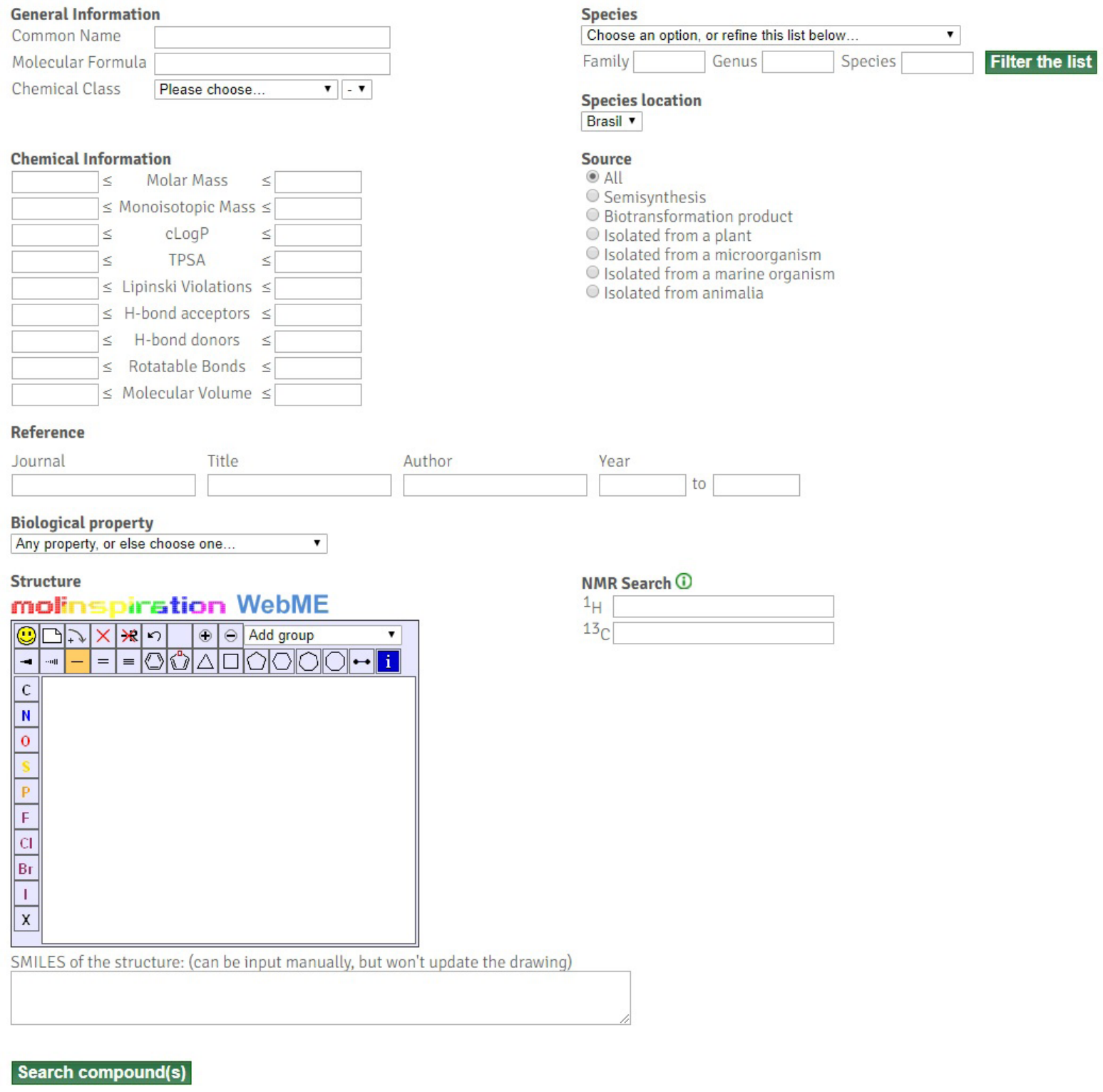

Figure 11 - Layout of the search platform on $\mathrm{NuBBE}_{\mathrm{DB}}$ website.

complex sample. This objective is possible with the development of more sensitive mass spectrometry (MS), nuclear magnetic resonance (NMR) and high performance liquid chromatography (HPLC), used for the identification of pure secondary metabolites or in complex mixtures, reducing the amount of sample for research and the time required for analysis.

Metabolomics (which consist in a set of qualitative and quantitative data on the secondary metabolites of a given biological origin matrix) is a strategy widely used in European and Asian countries to validate plants for human use. This kind of study consists in comparative analysis on metabolites from different samples, therefore, a metabolomics study should approach analytical methods considering all inherent chemical characteristics from the natural product classes studied. This information should contain all secondary metabolites present in the studied sample. 


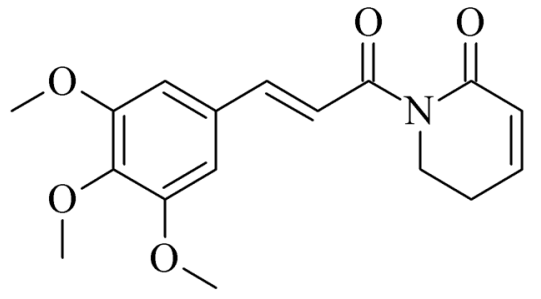

Piperlongumine (29)

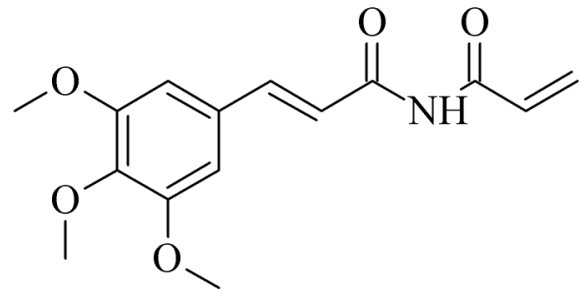

30

Figure 12 - Piperlongumine (29), an amide alkaloid isolated from Piper species and its biologically active simplified analogue (30).

It has become a robust tool to answer questions about how organisms of our great biodiversity interact with the environment, and can be a very useful tool for the rapid validation of herbal medicines, nutraceuticals and drugs in Brazil. The Brazilian Ministry of Health produced a list of medicinal useful plants of interest for the health care system (SUS) and the use of new analytical methodologies is an excellent experimental approach to Brazilian scientific and technological research of plants, and an opportunity for the national and global drug market (Funari et al. 2013).

The very important areas that could boost bioeconomy are metabolic engineering and biotechnology. Biotechnology is one of the most important technological tools today and has contributed to improve economic and social systems. It has contributed enormously to the treatment of diseases, the preparation of new medicines for human and animal application, the improved reproduction of plant and animal species, the development and improvement of food, the sustainable use of biodiversity and the recovery and treatment of waste (Decreto 2017).

Biocatalysis, for example, is being used to lower fossil-based products use, and improve sustainability, efficiency and cost of chemical production and could be used in the production of biofuels, surfactants and plastics. It can be developed using cellular extracts, cells or enzymes, and provides outstanding selectivity, avoiding several protection and deprotection steps in chemical reactions. Therefore, biocatalysis can be cheap, simplify processes, require milder reaction conditions, can be used with water as solvent and reduce waste. The production process of the topselling drug Atorvastatin uses biotransformation to improve production by synthesizing two chiral centers of the side chain (Murphy 2011).

This is an opportunity for a development based on knowledge and innovation, increase exports of high added value products with, clean production and lessen environmental impact. In 30 years Brazil has tripled the scientific contribution worldwide, and has trained professionals. In spite of the great competitiveness and growing exports of agroindustry and commodities, a modest scientific success has been converted in technological products and processes. There are more than 1700 research groups developing biotechnology research activity with a potential to interact with companies. There are also some sectors of the economy that already rely on biotechnological processes and products in their activities. Considering the chemical, genetic and biochemical diversity present in Brazilian biodiversity, Brazil has a universe of opportunities for biotechnological innovation. In addition, the regional distribution of this biodiversity creates opportunities for local economic development, and leverage of social development (Decreto 2017). 


\section{CONCLUSIONS}

Brazilian biodiversity is undoubtedly vast. Nevertheless, few products have emerged from this rich chemical universe. This rich biodiversity could be in-between the main sources for discoveries in natural products which could be applied to improve the quality of life of the world population. The serious problems that the world population is facing regarding the sustainable use of the earth resources urgently needs to be addressed. The use of new technologies on natural products research field, such as metabolomics and biotechnology, has been contributing for a more sustainable approach, decreasing the amount of wastes and using greener solvents. Since biotechnology and bio-based products are gaining attention due to the renewable sources and greener solutions for challenges of the modern world, Brazil could become a leader on bioeconomy, especially for all the potential and advantages nature has provided this country. This article gives a brief overview of Brazilian natural products that were successfully used to develop new products, and recent research performed in NuBBE laboratories on secondary metabolites from Brazilian biodiversity that could be further explored with potential application for new products and technologies. However, to deepen this approach, it is important to have good preservation policies and scientific programs in order to improve scientific research focused on bioeconomy, which could provide universe great deal of opportunities in our territory.

\section{ACKNOWLEDGMENTS}

The authors wish to acknowledge Fundação de Amparo à Pesquisa do Estado de São Paulo (FAPESP) grant \# 2013/07600-3, CIBFar, CEPID, grant 465637/2014-0, INCT BioNat CNPq/ FAPESP, \#2013/07600-3, BIOTA-FAPESP grant \#03/02176-7, SISBIOTA-CNPq-FAPESP grant \#2010/52327-5, Coordenação de Aperfeiçoamento de Pessoal de Nível Superior (CAPES), and Conselho Nacional de Desenvolvimento Científico e Tecnológico (CNPq) for grant support and research fellowships. MV acknowledges scholarship \#167874/2014-4 and \#152243/2016-0 from CNPq; HMR acknowledges scholarship \#152341/2015-2 from CNPq.

\section{REFERENCES}

BARREIRO EJ AND BOLZANI VS. 2009. Biodiversidade: fonte potencial para a descoberta de fármacos. Quim Nova 32: 679-688.

BOLZANI VS, GUNATILAKA AAL AND KINGSTON DGI. 1995. Bioactive and other piperidine alkaloids from Cassia leptophylla. Tetrahedron. 51: 5929-5934.

BOLZANI VS, VALLI M, PIVATTO M AND VIEGAS JR C. 2012. Natural products from Brazilian biodiversity as a source of new models for medicinal chemistry. Pure and Applied Chemistry 84: 1837-1846.

BRUGGE MM, HANSEN T AND KLITKOU A. 2016. What Is the Bioeconomy? A Review of the Literature. Sustainability 8: 691-713.

BUSS AD AND WAIGH RD. 1995. Natural products as leads for new pharmaceuticals. In: Wolff ME (Ed), Burger's medicinal chemistry and drug discovery. Principles and practice. Vol. 1. J Wiley \& Sons, Inc. New York, NY, p. 983-1033.

CALIXTO JB. 2000. Efficacy, safety, quality control, marketing and regulatory guidelines for herbal medicines (phytotherapeutic agents). Braz J Med Biol Res 33: 179189.

CIRIMINNA R, LOMELI-RODRIGUEZ M, CARÀ PD, LOPEZ-SANCHEZ JA AND PAGLIARO M. 2014. Limonene: a versatile chemical of the bioeconomy. Chem Comm 50: 15288-15296.

COQUEIRO A, CHOI YH, VERPOORTE R, GUPTA KB, DE MIERI M, HAMBURGER M, YOUNG MC, STAPLETON P, GIBBONS S AND BOLZANI VS. 2016. Antistaphylococcal Prenylated Acylphoroglucinol and Xanthones from Kielmeyera variabilis. J Nat Prod 79: 470-476.

CUENDET M, OTEHAM CP, MOON RC AND PEZZUTO JM. 2006. Quinone reductase induction as a biomarker for chancer chemoprevention. J Nat Prod 69: 460-463.

DECRETO. 2017. Available at: http://www.planalto.gov.br/ ccivil_03/_ato2007-2010/2007/decreto/d6041.htm.

EL-CHICHAKLI B, VON BRAUN J, LANG C, BARBEN D AND PHILP J. 2016. Five cornerstones of a global bioeconomy. Nature 53: 221-223. 
FERNANDES ES, PASSOS GF, MEDEIROS R, CUNHA FM, FERREIRA J, CAMPOS MM, PIANOWSKI LF AND CALIXTO JB. 2007. Anti-inflammatory effects of compounds alpha-humulene and (-)-trans-caryophyllene isolated from the essential oil of Cordia verbenacea. Eur J Pharmacol 569: 228-236.

FERREIRA SH, BARTELT DC AND GREENE LJ. 1970. Isolation of bradykinin-potentiating peptides from Bothrops jararaca venom. Biochem 9: 2583-2593.

FUNARI CS, CASTRO-GAMBOA I, CAVALHEIRO AJ AND BOLZANI VS. 2013. Metabolômica, uma abordagem otimizada para exploração da biodiversidade brasileira: estado da arte, perspectivas e desafios. Quim Nova 36: 1605-1609.

GALLAGHER KP AND PORZECANSKI R. 2010. The Dragon in the Room: China and the Future of Latin American Industrialization. Stanford University Press, $198 \mathrm{p}$.

GOTTLIEB R AND MORS WB. 1980. Potential utilization of Brazilian wood extractives. J Agric Food Chem 28: 196215.

HARVEY AL, EDRADA-EBEL RA AND QUINN RJ. 2015. The re-emergence of natural products for drug discovery in the genomics era. Nature 14: 111-129.

HORIOT JC ET AL. 2000. Post-radiation severe xerostomia relieved by pilocarpine: a prospective French cooperative study. Radiother Oncol 55: 233-239.

INPI - INSTITUTO NACIONAL DE PROPRIEDADE INDUSTRIAL. 2017. Available at: http://www.inpi.gov. $\mathrm{br} /$ sobre/planejamento.

JOLY CA, RODRIGUES RR, METZGER JP, HADDAD CFB, VERDADE LM, OLIVEIRA MC AND BOLZANI VS. 2010. Biodiversity conservation research, training, and policy in São Paulo. Science 328: 1358-1359.

KUENEMANN MA, LABBÉ CM, CERDAN AH AND SPERANDIO O. 2016. Imbalance in chemical space: how to facilitate the identification of protein-protein interaction inhibitors. Sci Rep 6: 23815.

LABATE BC AND FEENEY K. 2012. Ayahuasca and the process of regulation in Brazil and internationally: Implications and challenges. Int J Drug Pol 23: 154-161.

MCKENNA DJ, CALLAWAY JC AND GROB CS. 1998. The Scientific Investigation of Ayahuasca: A Review of Past and Current Research. The Heffter Review of Psychedelic Research 1: 65-76.

MINATEL DG, PEREIRA AMS, CHIARATTI TM, PASQUALIN L, OLIVEIRA JCN, COUTO LB, LIA RCC, CINTRA JM, BEZZON MFA AND FRANCA SC. 2010. Estudo clínico para validação da efícácia de pomada contendo barbatimão (Stryphnodendron adstringens ( Mart.) Coville)* na cicatrização de úlceras de decúbito. Rev Bras Medicina 67: 250-256.
MMA - Ministério do Meio Ambiente. 2017. Available at: www.mma.gov.br/portalbio.

MOHAMED A, NGUYEN CH AND MAMITSUKA H. 2016. Current status and prospects of computational resources for natural product dereplication: a review. Brief Bioinform 17: 309-321.

MURPHY AC. 2011. Metabolic engineering is key to a sustainable chemical industry. Nat Prod Rep 28: 14061425.

MYERS N, MITTERMELER RA, MITTERMELER CG, FONSECA GAB AND KENT J. 2000. Biodiversity hotspots for conservation priorities. Nature 403: 853-858.

NEVES BJ, ANDRADE CH AND CRAVO PVL. 2015. Natural products as leads in schistosome drug discovery. Molecules 20: 1872-1903.

NEWMAN DJ AND CRAGG GM. 2016. Natural Products as Sources of New Drugs from 1981 to 2014. J Nat Prod 79: 629-661.

NOSS RF. 1990. Indicators for Monitoring Biodiversity: A Hierarchical Approach. Conserv Biol 4: 355-364.

NUBBEDB. 2017. NuBBE database. Available at: http:// nubbe.iq.unesp.br/nubbeDB.html.

PASSOS GF, FERNANDES ES, CUNHA FM, FERREIRA J, PIANOWSKI LF, CAMPOS MM AND CALIXTO JB. 2007. Anti-inflammatory and anti-allergic properties of the essential oil and active compounds from Cordia verbenacea. J Ethnopharmacol 110: 323-333.

PAVARINI DP ET AL. 2012. Application of MALDI-MS analysis of Rainforest chemodiversity: a keystone for biodiversity conservation and sustainable use. J Mass Spectrom 47: 1482-1485.

PHILP J. 2015. Balancing the bioeconomy: supporting biofuels and bio-based materials in public policy. Energy Environ Sci 8: 3063-3068.

PILON AC, VALLI M, DAMETO AC, PINTO MEF, FREIRE RT, CASTRO-GAMBOA I, ANDRICOPULO AD AND BOLZANI VS. 2017. $\mathrm{NuBBE}_{\mathrm{DB}}$ : an updated database to uncover chemical and biological information from Brazilian biodiversity. Sci Rep 7:7215.

PINTO ME ET AL. 2015. Ribifolin, an orbitide from jatropha ribifolia, and its potential antimalarial activity. J Nat Prod 78: 374-380.

PIVATTO M, CROTTI AEM, LOPES NP, CASTROGAMBOA I, REZENDE A, VIEGAS JR. C, YOUNG MCM, FURLAN M AND BOLZANI VS. 2005. Electrospray ionization mass spectrometry screening of piperidine alkaloids from Senna spectabilis (Fabaceae) extracts: fast identification of new constituents and cometabolites. J Braz Chem Soc 16: 1431-1438.

QUEIROZ MM, MARTI G, QUEIROZ EF, MARCOURT L, CASTRO-GAMBOA I, BOLZANI VS AND WOLFENDER JL. 2015. LC-MS/MS quantitative determination of Tetrapterys mucronata alkaloids, a plant 
occasionally used in Ayahuasca preparation. Phytochem Anal 26: 183-188.

QUEIROZ MM, QUEIROZ EF, ZERAIK ML, EBRAHIMI SN, MARCOURT L, CUENDET M, CASTROGAMBOA I, HAMBURGER M, DA SILVA BOLZANI V AND WOLFENDER JL. 2014. Chemical composition of the bark of Tetrapterys mucronata and identification of acetylcholinesterase inhibitory constituents. J Nat Prod 77: 650-656.

RAJ L ET AL. 2011. Selective killing of cancer cells by a small molecule targeting the stress response to ROS. Nature 475: 231-234.

RSB - ROYAL SOCIETY OF BIOLOGY. 2017. Available at: https://www.rsb.org.uk/images/RSB_response_to the BEIS_Bioeconomy_consultation_Final_response.pdf.

SABANDAR CW, AHMAT N, JAAFAR FM AND SAHIDIN I. 2013. Medicinal property, phytochemistry and pharmacology of several Jatropha species (Euphorbiaceae): a review. Phytochem 85: 7-29.

SAMOYLENKO V, RAHMAN MM, TEKWANI BL, TRIPATHI LM, WANG YH, KHAN SI, KHAN IA, MILLER LS, JOSHI VC AND MUHAMMAD I. 2010. Banisteriopsis caapi, a unique combination of MAO inhibitory and antioxidative constituents for the activities relevant to neurodegenerative disorders and Parkinson's disease. J Ethnopharmacol 127: 357-367.

SILVA DHS, CASTRO-GAMBOA I AND BOLZANI VS. 2010. Plant Diversity from Brazilian Cerrado and Atlantic Forest as a Tool for Prospecting Potential Therapeutic Drugs. In: Mander L and Lui HW (Eds), Comprehensive Natural Products II Chemistry and Biology, Oxford: Elsevier, p. 95-133.

SILVA GH ET AL. 2017. Lactone Derivatives Produced by a Phaeoacremonium sp., an Endophytic Fungus from Senna spectabilis. J Nat Prod 80: 1674-1678.

SOS MATA ATLÂNTICA. 2017. Available at: www. sosmatatlantica.org.br.

SOUZA TM, MOREIRA RRD, PIETRO RCLR AND ISAAC VLB. 2007. Avaliação da atividade anti-séptica de extrato seco de Stryphnodendron adstringens (Mart.) Coville e de preparação cosmética contendo este extrato. Rev Bras Farmacogn 17: 71-75.

VALLI M ET AL. 2016. Synthetic Analogue of the Natural Product Piperlongumine as a Potent Inhibitor of Breast Cancer Cell Line Migration. J Braz Chem Soc 28: 475484.

VALLI M, BETTI AH, DANUELLO A, PIVATTO M, CENTURIÃO F, ANTONIO CB, RATES SM AND BOLZANI VS. 2015. Pyridinic analog of the natural product (-)-spectaline as potential adjuvant for the treatment of central nervous system disorders. Bioorg Med Chem Lett 25: 2247-2250.

VALLI M ET AL. 2011. Anticholinesterasic, nematostatic and anthelmintic activities of pyridinic and pyrazinic compounds. Curr Med Chem 18: 3423-3430.

VALLI M, PIVATTO M, DANUELLO A, SILVA DHS, CASTRO-GAMBOA I, CAVALHEIRO AJ, ARAÚJO AR, FURLAN M, LOPES MN AND BOLZANI VS. 2012. The Tropical Biodiversity: has it been a potential source of secondary metabolites useful for medicinal chemistry? Química Nova 35: 2278-2287.

VALLI M, SANTOS RN, FIGUEIRA LD, NAKAJIMA CH, ANDRICOPULO AD AND BOLZANI VS. 2013. Development of a natural products database from the biodiversity of Brazil. J Nat Prod 76: 439-444.

VIEGAS C JR, BOLZANI VS, FURLAN M, BARREIRO EJ, YOUNG MC, TOMAZELA D AND EBERLIN MN. 2004. Further bioactive piperidine alkaloids from the flowers and green fruits of Cassia spectabilis. J Nat Prod 67: 908-910.

VIEGAS JR C ET AL. 2005. New selective acetylcholinesterase inhibitors designed from natural piperidine alkaloids. Bioorg Med Chem 13: 4184-4190.

VILLOUTREIX BO, LAGORCE D, LABBÉ CM, SPERANDIO O AND MITEVA MA. 2013. One hundred thousand mouse clicks down the road: selected online resources supporting drug discovery collected over a decade. Drug Disc Today 18: 1081-1089.

WHO - WORLD HEALTH ORGANIZATION. 2017a. Available at: http://www.who.int/mediacentre/ factsheets/2003/fs134/en/.

WHO - WORLD HEALTH ORGANIZATION. 2017b. Available at: http://apps.who.int/gho/data/view. main.14112?lang=en.

WILSON EO. 1999. The Diversity of Life. New York: Harvard University Press, $424 \mathrm{p}$.

ZERAIK ML, QUEIROZ EF, MARCOURT L, CICLET O, CASTRO-GAMBOA I, SILVA DHS, CUENDET M, BOLZANI VS AND WOLFENDER JL. 2016. Antioxidants, quinone reductase inducers and acetylcholinesterase inhibitors from Spondias tuberosa fruits. J Functional Foods 21: 396-405.

ZERAIK ML, SERTEYN D, DEBY-DUPONT G, WAUTERS JN, TITS M, YARIWAKE JH, ANGENOT L AND FRANCK T. 2011. Evaluation of the antioxidant activity of passion fruit (Passiflora edulis and Passiflora alata) extracts on stimulated neutrophils and myeloperoxidase activity assays. Food Chem 128: 259-265. 